\title{
Syntheses and Chelating Properties of Azothiopyrines
}

\author{
Tomoo Tanaka* and Kuniyuki Tanaka \\ Meiji College of Pharmacy, 1-35-23 Nozawa, Setagaya-ku, Tokyo 154, Japan
}

(Received July 22, 1980)

\begin{abstract}
Azothiopyrine and methyl-azothiopyrine were synthesized as new chelating agents which form stable chelates with some metal ions at the mercapto and azo groups. Azothiopyrines are unusually stable in solution because of a strong intramolecular hydrogen bond between the mercapto and azo groups. The chelates of azothiopyrines with nickel(II), cobalt(II), copper(II), zinc(II), cadmium(II), mercury(II), palladium(II) and silver(I) were prepared in a neutral or slightly acidic medium, and characterized by elementary analysis, and visible and ultraviolet absorption spectroscopy. The metal chelates are stable, insoluble in water, and extractable into some organic solvents, and the excess azothiopyrines can be removed by extraction with sodium hydroxide solution without decomposition of the metal chelates. Azothiopyrines may be applicable to extraction spectrophotometric determination of such metal ions as palladium(II), mercury(II), copper(II), nickel(II) and cobalt(II), in view of the high molar extinction coefficients of the chelates.
\end{abstract}

Keywords-azothiopyrine; methyl-azothiopyrine; mercapto and azo groups; bidentate ligand; chelating ability; metal chelates; extraction of metal ions

Chelating agents bearing hydroxyl and azo groups as a chelate-forming site, such as Eriochrome Black T, Hydroxynaphthol Blue, and Pyridylazonaphthol, have been studied extensively and used widely as analytical reagents. ${ }^{1)}$ In contrast, the synthesis of azo compounds bearing a mercapto group has never been achieved. In an attempt to investigate the characteristics and applicability of mercapto azo compounds as analytical reagents, we synthesized azothiopyrines (5-mercapto-3-methyl-1-phenyl-4-phenyldiazenyl-1,2-diazacyclopenta2,4-diene and 1,3-dimethyl-5-mercapto-4-phenyldiazenyl-1,2-diazacyclopenta-2,4-diene) by the procedure shown in Chart 1 . In the design of these chelating agents and the synthetic procedures, the following findings and considerations were taken into account. Thiopyrine (2,3dimethyl-1-phenyl-5-thioxo-1,2-diazacyclopent-3-ene) was found to behave as a sulfur donortype monodentate ligand, forming stable complexes with some metal ions, which reacted with the thione group. ${ }^{2}$ 3-Methyl-1-phenyl-5-thioxo-1,2-diazacyclopent-3-ene was found to be easily oxidized to the disulfide in air and to prefer the thiol to the amide form in nonpolar solvents. ${ }^{3)}$ Azothiopyrines are expected to be stable (with an intramolecular hydrogen bond between the mercapto and azo groups) and to have strong chelating ability for metal ions of $b$ character. The diazacyclopenta-2,4-diene ring is expected to be stable in the synthetic
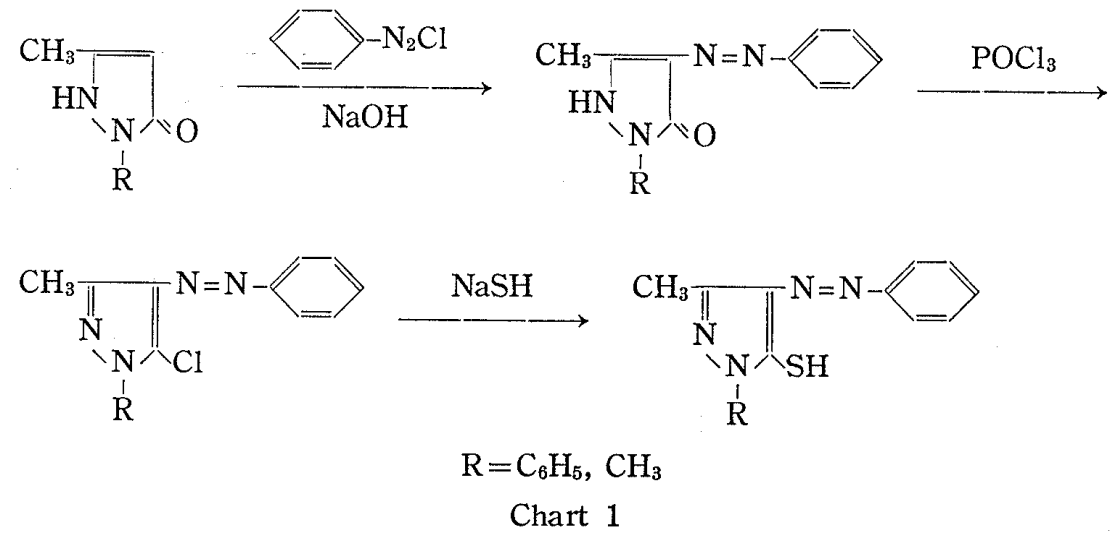
procedure. A chlorine atom in the diazacyclopenta-2,4-diene ring is highly reactive and is expected to be replaced by a mercapto group with ease. As expected, azothiopyrine (IVa) and methyl-azothiopyrine (IVb) were obtained in good yields, representing the first reported examples of chelating agents bearing mercapto and azo groups.

The nuclear magnetic resonance (NMR) spectra of azothiopyrine and methyl-azothiopyrine in deuterated chloroform showed proton signals due to the thiol group in the low range of magnetic field, at 16.68 and $16.20 \mathrm{ppm}$, respectively. The presence of an intramolecular hydrogen bond in azothiopyrines, as shown in Chart 2, was supported by their absorption spectra. Namely, absorption maxima of azothio-

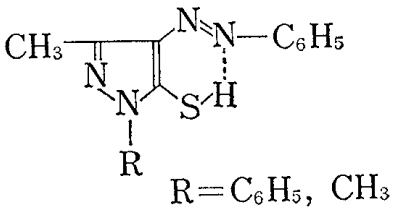

Chart 2 pyrines (IVa, IVb) were observed at $45-50 \mathrm{~nm}$ longer wavelength than those of the chloro (IIIa, IIIb) and S-methyl (Va, Vb) derivatives. The absorption spectra of azothiopyrines in ethanol remained unchanged during storage for as long time as a year or more, so that azothiopyrines were found to be quite stable and could be stored in solution under air without being oxidized.

The reactions between azothiopyrines and metal ions were examined by spot tests. The results showed that azothiopyrines form metal chelates with metal ions which have $b$ and

TABLE I. Absorption Spectral Data for Azothiopyrine and Its Metal Chelates in Chloroform

\begin{tabular}{lllll}
\hline \hline Compounds & \multicolumn{3}{l}{$\lambda_{\max } \mathrm{nm}\left(10^{-3} \varepsilon\right)$} \\
\hline $\mathrm{RH}$ & $260(18.3)$, & $405(24.0)$, & $475^{*}(8.2)$ & \\
$\mathrm{R}_{2} \mathrm{Ni}(\mathrm{II})$ & $295(34.4)$, & $360(29.2)$, & & $550^{*}(3.0)$ \\
$\mathrm{R}_{2} \mathrm{Co}(\mathrm{II})$ & & $355^{*}(28.7)$, & $390(31.4)$, & $600^{*}(1.1)$ \\
$\mathrm{R}_{2} \mathrm{Cu}(\mathrm{II})$ & & $355(43.6)$, & $455(9.9)$, & $635(3.8)$ \\
$\mathrm{R}_{2} \mathrm{Zn}(\mathrm{II})$ & & $380(29.3)$, & $450(22.2)$ & \\
$\mathrm{R}_{2} \mathrm{Cd}(\mathrm{II})$ & & $355(27.9)$, & $440(20.1)$ & \\
$\mathrm{R}_{2} \mathrm{Hg}(\mathrm{II})$ & & $335(26.0)$, & $425^{*}(10.8)$ & \\
$\mathrm{R}_{2} \mathrm{Pd}(\mathrm{II})$ & $275^{*}(41.7)$, & $345(27.4)$, & & $505(5.8)$ \\
$\mathrm{RPd}(\mathrm{II}) \mathrm{Cl}$ & $265^{*}(29.6)$, & $360(13.4)$, & $460^{*}(3.8)$ & \\
$\mathrm{RAg}(\mathrm{I})$ & & $345(15.4)$ & & \\
\hline
\end{tabular}

$\mathrm{RH}=$ azothiopyrine $\left(\mathrm{C}_{16} \mathrm{H}_{14} \mathrm{~N}_{4} \mathrm{~S}\right)$.

* shoulder or inflection.

TABLE II. Absorption Spectral Data for Methyl-azothiopyrine and Its Metal Chelates in Chloroform

\begin{tabular}{llllll}
\hline \hline Compounds & \multicolumn{5}{c}{$\lambda_{\max } \mathrm{nm}\left(10^{-3} \varepsilon\right)$} \\
\hline $\mathrm{RH}$ & $267(28.5)$, & $290^{*}(21.4)$, & $346(25.9)$, & & \\
$\mathrm{R}_{2} \mathrm{Ni}(\mathrm{II})$ & $345^{*}(24.0)$, & $375(25.1)$, & $450^{*}(13.3)$, & $600^{*}(1.0)$ \\
$\mathrm{R}_{2} \mathrm{Co}(\mathrm{II})$ & & $350(40.5)$, & $450(10.8)$, & $625(3.1)$ \\
$\mathrm{R}_{2} \mathrm{Cu}(\mathrm{II})$ & & $353(24.7)$, & $450(22.5)$ & \\
$\mathrm{R}_{2} \mathrm{Zn}(\mathrm{II})$ & & $347(22.7)$, & $445(20.2)$ & \\
$\mathrm{R}_{2} \mathrm{Cd}(\mathrm{II})$ & & $325(20.8)$, & $370^{*}(12.6)$, & $425^{*}(9.6)$ & \\
$\mathrm{R}_{2} \mathrm{Hg}(\mathrm{II})$ & & $325(25.1)$, & & & \\
$\mathrm{R}_{2} \mathrm{Pd}(\mathrm{II})$ & $257(39.1)$, & $355(12.3)$, & & \\
$\mathrm{RPd}(\mathrm{II}) \mathrm{Cl}$ & & $337(10.0)$, & $395^{*}(6.9)$ & & \\
$\mathrm{RAg}(\mathrm{I})$ & & & & & \\
\end{tabular}

$\mathrm{RH}=$ methyl-azothiopyrine $\left(\mathrm{C}_{11} \mathrm{H}_{12} \mathrm{~N}_{4} \mathrm{~S}\right)$.

* shoulder or inflection. 
borderline character, namely nickel(II), cobalt(II), copper(II), zinc(II), cadmium(II), mercury(II), palladium(II) and silver(I), but not with metal ions which have a character, namely chromium(III), aluminum(III), iron(II), calcium(II) and magnesium(II). These metal chelates were isolated in pure state. The results of elemental analyses of metal chelates with nickel(II), cobalt(II), copper(II), zinc(II), cadmium(II) and mercury(II) showed a metal-to-ligand ratio of $1: 2$, while the results for silver (I) chelate showed a ratio of $1: 1$. The copper(II) chelate was prepared by shaking copper(II) acetate and an azothiopyrine in benzene. However, when copper(II) acetate was added to an ethanol solution of an azothiopyrine, a compound insoluble in organic solvents precipitated. This compound was probably copper(I) chelate, but it was not obtained in a pure state. The formation of copper(I) chelate was interpreted in terms of the apparent oxidation of the ligand to its disulfide and the reduction of copper(II) to copper(I), which then reacted with the ligand present in excess. In the reaction of palladium(II), two kinds of chelates were obtained with metal-to-ligand ratios of 1:2 and 1:1 in the presence of excess ligand and excess metal ion. These isolated metal chelates were found to be extractable into organic solvents such as benzene, chloroform and 1,2-dichloroethane. Tables I and II indicate the absorption maxima and molar absorptivities of the reagents and the metal chelates in chloroform. As shown in Fig. 1, the extractions of metal ions with benzene were found to be quantitative from the following media, namely $5 \mathrm{~N} \mathrm{HCl}-\mathrm{pH} 12$ for palla$\operatorname{dium}(\mathrm{II}), 0.1 \mathrm{~N} \mathrm{HCl}-\mathrm{pH} 12$ for mercury (II), pH 3-11 for copper(II), pH 6-10 for nickel(II) and $\mathrm{pH} 8-10$ for cobalt (II). The excess reagent could be removed completely from the benzene layer by the use of sodium hydroxide solution without any decomposition of the metal chelates. Azothiopyrines may be useful for the extractionspectrophotometric determination of palladium(II), mercury(II), copper(II), nickel(II) and cobalt(II). The high stability of azothiopyrines in dilute

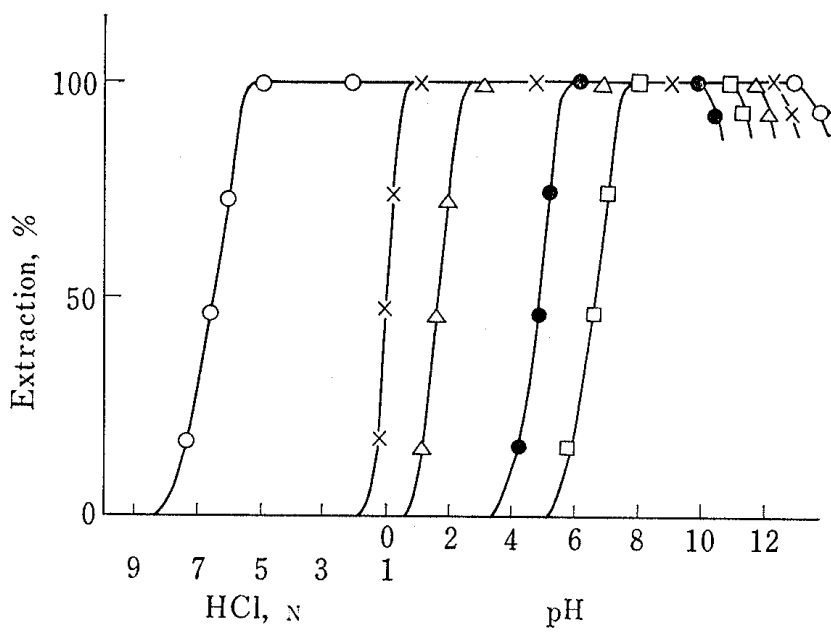

Fig. 1. Extraction of Methyl-azothiopyrine Metal Chelates with Benzene at Various $\mathrm{pH}$ Values

Benzene: $10 \mathrm{ml}$. 0.1\% Methyl-azothiopyrine $\mathrm{MeOH}$ solution: $1 \mathrm{ml} .-\mathrm{O}-\mathrm{Pd}(\mathrm{II}) 40 \mu \mathrm{g} .-X-: \mathrm{Hg}(\mathrm{II}) 40 \mu \mathrm{g} .-\triangle-$ : $\mathrm{Cu}$ (II) $15 \mu \mathrm{g}$. - $: \mathrm{Ni}(\mathrm{II}) 15 \mu \mathrm{g}$. - $\square-\mathrm{Co}$ (II) $15 \mu \mathrm{g}$. The absorbances of the extracts were measured at $325 \mathrm{~nm}$ for $\mathrm{Pd}(\mathrm{II}), 330 \mathrm{~nm}$ for $\mathrm{Hg}(\mathrm{II}), 350 \mathrm{~nm}$ for $\mathrm{Cu}(\mathrm{II}), 350 \mathrm{~nm}$ for $\mathrm{Ni}(\mathrm{II})$, and $370 \mathrm{~nm}$ for $\mathrm{Co}(\mathrm{II})$. solution is advantageous.

Snavely et al. ${ }^{4)}$ reported that 3-methyl-5-oxo-1-phenyl-4-phenyldiazenyl-1,2-diazacyclopent-3-ene (an oxygen analog of azothiopyrine) did not form metal chelates with $b$ character metal ions such as mercury (II), cadmium (II) and silver (I). The selectivity of azothiopyrine towards the metal ions is attributable to the presence of sulfur as a donor atom.

\section{Experimental}

Melting points were obtained on a Yazawa micro melting point apparatus and are uncorrected. Ultraviolet and visible spectra were recorded with a Hitachi model 200-10 spectrophotometer. Nuclear magnetic resonance spectra were measured on a JEOL JNM-PS-100 spectrophotometer, with tetramethylsilane as an internal standard.

3-Methyl-5-oxo-1-phenyl-4-phenyldiazenyl-1,2-diazacyclopent-3-ene (IIa) and 1,3-Dimethyl-5-oxo-4phenyldiazenyl-1,2-diazacyclopent-3-ene (IIb)_-The azo compounds were prepared by coupling the appropriate diazotized aniline to 3-methyl-5-oxo-1-phenyl-1,2-diazacyclopent-3-ene (Ia) or 1,3-dimethyl-5-oxo-1,2diazacyclopent-3-ene (Ib) in sodium hydroxide solution, according to the method outlined by Snavely et al. ${ }^{4}$ ) 
Yields, 85-90\%. IIa: orange needles, mp 154-155.$\quad$ UV $\lambda_{\max }^{\text {Etor }} \mathrm{nm}(\log \varepsilon): 392$ (4.39), 250 (4.37). IIb: orange needles, $\mathrm{mp} 115-116^{\circ}$. UV $\lambda_{\max }^{\mathrm{EtoH}} \mathrm{nm}(\log \varepsilon): 384$ (4.22), 250 (3.89).

5-Chloro-3-methyl-1-phenyl-4-phenyldiazenyl-1,2-diazacyclopenta-2,4-diene (IIIa)_-A mixture of $15 \mathrm{~g}$ of IIa and $12.5 \mathrm{~g}$ of $\mathrm{POCl}_{3}$ was heated at $100-105^{\circ}$ for $3 \mathrm{hr}$. The reaction mixture was poured into ice-water, neutralized with $\mathrm{NaOH}$ solution, and extracted with $\mathrm{CHCl}_{3}$. The extract was dried over anhydrous $\mathrm{Na}_{2} \mathrm{SO}_{4}$, and evaporated to dryness to yield a dark-brown solid product. This was purified by alumina column chromatography using $100 \mathrm{~g}$ of alumina, with $\mathrm{CHCl}_{3}$ as the eluent, to give yellow crystals. Recrystallization from benzene and petroleum benzin $(1: 3)$ gave yellow needles. Yield, $14 \mathrm{~g}(88 \%)$. mp $109-110^{\circ}$. Anal. Calcd for $\mathrm{C}_{16} \mathrm{H}_{13} \mathrm{ClN}_{4}: \mathrm{C}, 64.76 ; \mathrm{H}, 4.42 ; \mathrm{N}, 18.88$. Found: $\mathrm{C}, 64.92 ; \mathrm{H}, 4.48 ; \mathrm{N}, 18.92$. UV $\lambda_{\max }^{\text {EtoH }} \mathrm{nm}(\log \varepsilon)$ : 426 (2.99), 333 (4.41), 230 (4.19).

5-Chloro-1,3-dimethyl-4-phenyldiazenyl-1,2-diazacyclopenta-2,4-diene (IIIb)—A mixture of $15 \mathrm{~g}$ of $\mathrm{IIb}$ and $16 \mathrm{~g}$ of $\mathrm{POCl}_{3}$ was heated at $100-105^{\circ}$ for $3 \mathrm{hr}$. The reaction mixture was worked up by the method described for IIIa, to yield IIIb. Recrystallization from petroleum benzin gave yellow needles. Yield, $13.5 \mathrm{~g}(83 \%)$. $\mathrm{mp} 44-45^{\circ}$. Anal. Calcd for $\mathrm{C}_{11} \mathrm{H}_{11} \mathrm{ClN}_{4}: \mathrm{C}, 56.29 ; \mathrm{H}, 4.72 ; \mathrm{N}, 23.87$. Found: C, 56.47; $\mathrm{H}, 4.81 ; \mathrm{N}, 23.92$. UV $\lambda_{\max }^{\mathrm{EtOH}} \mathrm{nm}(\log \varepsilon): 425(2.91), 330(4.34), 230(4.05)$.

Azothiopyrine (IVa)—An aqueous solution $(50 \mathrm{ml}$ ) of $4.3 \mathrm{~g}$ of $70 \%$ (w/w) NaSH was added to $50 \mathrm{ml}$ of an EtOH solution of $10 \mathrm{~g}$ of IIIa, and then the mixture was heated for 20 min on a steam bath. The reaction mixture was cooled to room temperature, acidified with dil. $\mathrm{HCl}$, and extracted with $\mathrm{CHCl}_{3}$. The solvent was evaporated off, then the residue was dissolved in $50 \mathrm{ml}$ of benzene and petroleum benzin (1:4), and extracted repeatedly with $5 \% \mathrm{NaOH}$ solution. The combined aqueous extract was acidified with dil. $\mathrm{HCl}$, and extracted again with $\mathrm{CHCl}_{3}$. The extract was dried over anhydrous $\mathrm{Na}_{2} \mathrm{SO}_{4}$, and evaporated to dryness to give reddish crystals. They were recrystallized from benzene and petroleum benzin (1:3). Yield, $7.0 \mathrm{~g}(71 \%)$. Reddish-orange needles. $\mathrm{mp} 100-101^{\circ}$. Anal. Calcd for $\mathrm{C}_{16} \mathrm{H}_{14} \mathrm{~N}_{4} \mathrm{~S}: \mathrm{C}, 65.28 ; \mathrm{H}, 4.78 ; \mathrm{N}$, 19.03; S, 10.89. Found: $\mathrm{C}, 65.39 ; \mathrm{H}, 4.88 ; \mathrm{N}, 19.00 ; \mathrm{S}, 10.93$. UV $\lambda_{\max }^{\mathrm{EtoH}} \mathrm{nm}(\log \varepsilon): 475(3.88), 403(4.35)$, $260(4.20), 225$ (4.17). NMR ( $\left.\mathrm{CDCl}_{3}\right) \mathrm{ppm}: 2.44\left(3 \mathrm{H}, \mathrm{s}, \mathrm{CH}_{3}\right), 7.20-7.96\left(10 \mathrm{H}, \mathrm{m}, \mathrm{C}_{6} \mathrm{H}_{5}\right), 16.68(1 \mathrm{H}, \mathrm{s}, \mathrm{SH})$. The signal at $16.68 \mathrm{ppm}$ disappeared when the $\mathrm{CDCl}_{3}$ solution was shaken with $\mathrm{D}_{2} \mathrm{O}$.

Methyl-azothiopyrine (IVb) - This compound was prepared from $50 \mathrm{ml}$ of an aqueous solution of $5.5 \mathrm{~g}$ of $70 \%(\mathrm{w} / \mathrm{w}) \mathrm{NaSH}$ and $50 \mathrm{ml}$ of an EtOH solution of $10 \mathrm{~g}$ of IIIb by the method described for IVa. Recrystallization from petroleum benzin gave reddish-violet needles. Yield, $6.5 \mathrm{~g}(66 \%)$. mp 109-110 . Anal. Calcd for $\mathrm{C}_{11} \mathrm{H}_{12} \mathrm{~N}_{4} \mathrm{~S}: \mathrm{C}, 56.87 ; \mathrm{H}, 5.21 ; \mathrm{N}, 24.12 ; \mathrm{S}, 13.81$. Found: C, 57.01; H, 5.24; N, 24.08; S, 13.71 . UV $\lambda_{\max }^{\mathrm{EtOH}} \mathrm{nm}(\log \varepsilon): 477(3.92), 385(4.25), 233(4.22)$. NMR $\left(\mathrm{CDCl}_{3}\right)$ ppm: $2.37\left(3 \mathrm{H}, \mathrm{s}, \mathrm{CH}_{3}\right), 3.73(3 \mathrm{H}, \mathrm{s}$, $\left.\mathrm{CH}_{3}\right), 7.25-7.60\left(5 \mathrm{H}, \mathrm{m}, \mathrm{C}_{6} \mathrm{H}_{5}\right), 16.20(1 \mathrm{H}, \mathrm{s}, \mathrm{SH})$. The signal at $16.20 \mathrm{ppm}$ disappeared when the $\mathrm{CDCl}_{3}$ solution was shaken with $\mathrm{D}_{2} \mathrm{O}$.

3-Methyl-5-methylthio-1-phenyl-4-phenyldiazenyl-1,2 - diazacyclopenta - 2,4-diene (Va)- $-\mathrm{CH}_{3} \mathrm{I}$ (1.0 g) was added to $50 \mathrm{ml}$ of an EtOH solution of $1.0 \mathrm{~g}$ of IVa, and the mixture was refluxed gently for $30 \mathrm{~min}$. When the mixture had cooled to room temperature, the solvent was removed under reduced pressure, and the residue was recrystallized from petroleum benzin to give yellow needles. Yield, $0.9 \mathrm{~g}(86 \%)$. mp 58-59 . Anal. Calcd for $\mathrm{C}_{17} \mathrm{H}_{16} \mathrm{~N}_{4} \mathrm{~S}: \mathrm{C}, 66.21 ; \mathrm{H}, 5.23 ; \mathrm{N}, 18.17 ; \mathrm{S}, 10.40$. Found: C, 66.17; H, 5.24; N, 18.31; S, 10.48. UV $\lambda_{\max }^{\mathrm{EtOH}} \mathrm{nm}(\log \varepsilon): 425(3.11), 340(4.25), 233(4.13)$.

1,3-Dimethyl-5-methylthio-4-phenyldiazenyl-1,2-diazacyclopenta-2,4-diene (Vb)-This compound was prepared from $50 \mathrm{ml}$ of EtOH solution of $1.0 \mathrm{~g}$ of $\mathrm{IVb}$ and $1.3 \mathrm{~g}$ of $\mathrm{CH}_{3} \mathrm{I}$ by the method described for Va. Yellow needles. Yield, $0.9 \mathrm{~g}(85 \%)$. mp 50-51 ${ }^{\circ}$. Anal. Calcd for $\mathrm{C}_{12} \mathrm{H}_{14} \mathrm{~N}_{4} \mathrm{~S}: \mathrm{C}, 58.51 ; \mathrm{H}, 5.73 ; \mathrm{N}, 22.75$; $\mathrm{S}, 13.02$. Found: $\mathrm{C}, 58.66 ; \mathrm{H}, 5.92 ; \mathrm{N}, 23.02 ; \mathrm{S}, 13.06$. UV $\lambda_{\max }^{\text {EtoH }} \mathrm{nm}(\log \varepsilon): 430(3.00), 335(4.19), 232$ (4.03).

Preparation of Azothiopyrine Metal Chelates: Nickel(II), Cobalt(II), Zinc(II), Cadmium(II) and Mercury(II) Chelates_A A solution of azothiopyrine was prepared by dissolving $2.9 \mathrm{~g}$ of azothiopyrine in sufficient EtOH to produce $400 \mathrm{ml}$ of a $0.025 \mathrm{M}$ solution. To $40 \mathrm{ml}$ of this solution, $5 \mathrm{ml}$ of aqueous $0.2 \mathrm{~m}$ metal acetate was added. The metal chelate precipitated from the reaction mixture immediately. After standing in an ice bath for $1 \mathrm{hr}$, the precipitates were filtered off, and washed with $10 \mathrm{ml}$ of cold EtOH. The crude chelates were purified by recrystallization from benzene and EtOH (1:4). Yields, $80-90 \%$. The nickel(II) chelate was obtained as dark-brown needles. $\mathrm{mp} 225-227^{\circ}$. Anal. Calcd for $\mathrm{C}_{32} \mathrm{H}_{26} \mathrm{~N}_{8} \mathrm{NiS}_{2}$ : C, 59.55; H, 4.06; $\mathrm{N}, 17.36$. Found: $\mathrm{C}, 59.80 ; \mathrm{H}, 4.26 ; \mathrm{N}, 17.16$. The cobalt(II) chelate was obtained as chocolate-brown columns. mp 228-230'. Anal. Calcd for $\mathrm{C}_{32} \mathrm{H}_{26} \mathrm{CoN}_{8} \mathrm{~S}_{2}: \mathrm{C}, 59.53 ; \mathrm{H}, 4.06 ; \mathrm{N}, 17.35$. Found: C, 59.79; $\mathrm{H}, 4.21 ; \mathrm{N}, 17.46$. The zinc(II) chelate was obtained as reddish-orange columns. mp $225-227^{\circ}$. Anal. Calcd for $\mathrm{C}_{32} \mathrm{H}_{26} \mathrm{~N}_{8} \mathrm{~S}_{2} \mathrm{Zn}$ : C, 58.94; H, 4.02; N, 17.18. Found: C, 59.18; H, 4.10; N, 17.28. The cadmium(II) chelate was obtained as yellowish-orange fine needles. mp 262-264. Anal. Calcd for $\mathrm{C}_{32} \mathrm{H}_{26} \mathrm{CdN}_{8} \mathrm{~S}_{2}: \mathrm{C}_{\text {, }}$ 54.97; H, 3.75; N, 16.03. Found: C, 55.07; H, 3.78; N, 15.85. The mercury(II) chelate was obtained as yellowish-orange needles. mp $228-230^{\circ}$. Anal. Calcd for $\mathrm{C}_{32} \mathrm{H}_{26} \mathrm{HgN}_{8} \mathrm{~S}_{2}: \mathrm{C}, 48.82 ; \mathrm{H}, 3.33 ; \mathrm{N}, 14.23$. Found: C, $49.07 ; \mathrm{H}, 3.23 ; \mathrm{N}, 14.42$.

Silver(I) Chelate_- This chelate was prepared from $7 \mathrm{ml}$ of aqueous $0.2 \mathrm{~m}$ silver nitrate and $40 \mathrm{ml}$ of $0.025 \mathrm{~m}$ azothiopyrine solution in EtOH by the general method described above. Recrystallization from pyridine and EtOH $(1: 5)$ gave orange fine needles in similar yield. $\mathrm{mp} 285-287^{\circ}$ (dec.). Anal. Calcd for $\mathrm{C}_{16} \mathrm{H}_{13} \mathrm{AgN}_{4} \mathrm{~S}: \mathrm{C}, 47.90 ; \mathrm{H}, 3.27 ; \mathrm{N}, 13.96$. Found: C, 47.81; H, 3.29; N, 13.93 . 
Palladium(II) Chelate-(1) Palladium chloride $(80 \mathrm{mg})$ was dissolved in $2 \mathrm{ml}$ of $0.1 \mathrm{~N} \mathrm{HCl}$, and diluted with $10 \mathrm{ml}$ of EtOH. To this palladium solution, $40 \mathrm{ml}$ of $0.01 \mathrm{~m}$ azothiopyrine solution in EtOH was added. The resulting precipitates were filtered off, and recrystallized from benzene to give chocolatebrown fine needles. Yield, $90 \%$. $\operatorname{mp} 290-295^{\circ}$ (dec.). Anal. Calcd for $\mathrm{C}_{16} \mathrm{H}_{13} \mathrm{ClN}_{4} \mathrm{PdS}: \mathrm{C}, 44.16 ; \mathrm{H}, 3.01$; $\mathrm{N}, 12.87$. Found: $\mathrm{C}, 43.86 ; \mathrm{H}, 2.98 ; \mathrm{N}, 12.60$.

(2) The palladium chloride solution was prepared as described above. This solution was added to $40 \mathrm{ml}$ of $0.025 \mathrm{M}$ azothiopyrine solution in EtOH. The resulting precipitates were filtered off and recrystallized from benzene and EtOH $(1: 4)$ to give reddish-brown needles. Yield, 85\%. mp 287-289 . Anal. Calcd for $\mathrm{C}_{32} \mathrm{H}_{26} \mathrm{~N}_{8} \mathrm{PdS}_{2}: \mathrm{C}, 55.45 ; \mathrm{H}, 3.78 ; \mathrm{N}, 16.17$. Found: $\mathrm{C}, 55.56 ; \mathrm{H}, 3.82 ; \mathrm{N}, 16.03$.

Copper(II) Chelate-Aqueous $0.02 \mathrm{~m}$ cupric acetate in $\mathrm{pH} 3.5$ acetate buffer $(30 \mathrm{ml})$ was shaken with $30 \mathrm{ml}$ of a benzene solution of $300 \mathrm{mg}$ of azothiopyrine for $30 \mathrm{~min}$. The extracted benzene solution was evaporated to dryness under reduced pressure, and then the residue was recrystallized from benzene and EtOH (1:5) to give dark-green needles. Yield, 60\%. mp 202-204 (dec.). Anal. Calcd for $\mathrm{C}_{32} \mathrm{H}_{25} \mathrm{CuN}_{8} \mathrm{~S}_{2}: \mathrm{C}_{\text {, }}$ $59.11 ; \mathrm{H}, 4.03 ; \mathrm{N}, 17.23$. Found: $\mathrm{C}, 60.02 ; \mathrm{H}, 4.14 ; \mathrm{N}, 17.14$.

Preparation of Methyl-azothiopyrine Metal Chelates: Nickel(II), Cobalt(II), Zinc(II), Cadmium(II) and Mercury(II) Chelates_-A solution of methyl-azothiopyrine was prepared by dissolving $2.3 \mathrm{~g}$ of methylazothiopyrine in sufficient EtOH to produce $200 \mathrm{ml}$ of a $0.05 \mathrm{~m}$ solution. To $20 \mathrm{ml}$ of this solution, $5 \mathrm{ml}$ of aqueous $0.2 \mathrm{M}$ metal acetate was added. After standing at room temperature for $30 \mathrm{~min}$, the mixture was diluted with $30 \mathrm{ml}$ of water, then the whole was extracted with benzene. The extract was evaporated to dryness under reduced pressure, and the residue was recrystallized from benzene and petroleum benzin (1:5). Yields, 85-95\%. The nickel(II) chelate was obtained as dark-brown columns. mp 190-192 ${ }^{\circ}$. Anal. Calcd for $\mathrm{C}_{22} \mathrm{H}_{22} \mathrm{~N}_{8} \mathrm{NiS}_{2}: \mathrm{C}, 50.69 ; \mathrm{H}, 4.25 ; \mathrm{N}, 21.49$. Found: $\mathrm{C}, 50.57 ; \mathrm{H}, 4.32 ; \mathrm{N}, 21.83$. The cobalt(II) chelate was obtained as dark-brown columns. mp 218-220 . Anal. Calcd for $\mathrm{C}_{22} \mathrm{H}_{22} \mathrm{CoN}_{8} \mathrm{~S}_{2}: \mathrm{C}, 50.67$; $\mathrm{H}, 4.25 ; \mathrm{N}, 21.48$. Found : $\mathrm{C}, 50.79 ; \mathrm{H}, 4.20 ; \mathrm{N}, 21.55$. The zinc(II) chelate was obtained as orange columns. mp 207-209. Anal. Calcd for $\mathrm{C}_{22} \mathrm{H}_{22} \mathrm{~N}_{8} \mathrm{~S}_{2} \mathrm{Zn}: \mathrm{C}, 50.05 ; \mathrm{H}, 4.20 ; \mathrm{N}, 21.22$. Found: $\mathrm{C}, 50.20 ; \mathrm{H}, 4.15 ; \mathrm{N}$, 21.48. The cadmium(II) chelate was obtained as yellow fine needles. $\mathrm{mp} 178-180^{\circ}$. Anal. Calcd for $\mathrm{C}_{22} \mathrm{H}_{22} \mathrm{CdN}_{8} \mathrm{~S}_{2}: \mathrm{C}, 45.95 ; \mathrm{H}, 3.86 ; \mathrm{N}, 19.49$. Found: C, 46.00; H, 3.94; N, 19.68. The mercury(II) chelate was obtained as yellowish-orange columns. mp 195-197 . Anal. Calcd for $\mathrm{C}_{22} \mathrm{H}_{22} \mathrm{HgN}_{8} \mathrm{~S}_{2}: \mathrm{C}, 39.84 ; \mathrm{H}$, $3.34 ; \mathrm{N}, 16.90$. Found: $\mathrm{C}, 39.71 ; \mathrm{H}, 3.32 ; \mathrm{N}, 17.10$.

Silver $(\mathbf{I})$ Chelate-Aqueous $0.2 \mathrm{M}$ silver nitrate $(5 \mathrm{ml})$ was added to $40 \mathrm{ml}$ of $0.025 \mathrm{M}$ methyl-azothiopyrine EtOH solution. A yellow crystalline product was deposited immediately. After standing in an ice bath for $30 \mathrm{~min}$, the precipitate was filtered off, and recrystallized from pyridine and EtOH $(1: 5)$ to give orange fine needles. Yield, 85\%. mp 245-250 (dec.). Anal. Calcd for $\mathrm{C}_{11} \mathrm{H}_{11} \mathrm{AgN}_{4} \mathrm{~S}: \mathrm{C}, 38.95 ; \mathrm{H}, 3.27$; $\mathrm{N}, 16.52$. Found: $\mathrm{C}, 39.24 ; \mathrm{H}, 3.36 ; \mathrm{N}, 16.48$.

Palladium(II) Chelate-(1) Palladium chloride $(80 \mathrm{mg})$ was dissolved in $2 \mathrm{ml}$ of $0.1 \mathrm{~N} \mathrm{HCl}$, and the solution was diluted with $10 \mathrm{ml}$ of EtOH. To this solution, $40 \mathrm{ml}$ of $0.01 \mathrm{~m}$ methyl-azothiopyrine solution in EtOH was added. The resulting precipitates were collected, and recrystallized from dimethylformamide and $\mathrm{EtOH}(1: 3)$ to give yellowish-orange fine needles. Yield, 90\%. $\mathrm{mp} 320-325^{\circ}$ (dec.). Anal. Calcd for $\mathrm{C}_{11} \mathrm{H}_{11} \mathrm{ClN}_{4} \mathrm{PdS}: \mathrm{C}, 35.41 ; \mathrm{H}, 2.97 ; \mathrm{N}, 15.01$. Found: $\mathrm{C}, 35.33 ; \mathrm{H}, 2.85 ; \mathrm{N}, 14.78$.

(2) The palladium chloride solution was prepared as described above. This solution was added to $20 \mathrm{ml}$ of $0.05 \mathrm{M}$ methyl-azothiopyrine solution in EtOH. After standing for $30 \mathrm{~min}$, the mixture was diluted with $30 \mathrm{ml}$ of water, and extracted with benzene. The extract was evaporated to dryness, and the residue was recrystallized from benzene and petroleum benzin $(1: 5)$ to give reddish-orange needles. Yield, $85 \%$. mp 279-281 . Anal. Calcd for $\mathrm{C}_{22} \mathrm{H}_{22} \mathrm{~N}_{8} \mathrm{PdS}_{2}: \mathrm{C}, 46.44 ; \mathrm{H}, 3.90 ; \mathrm{N}, 19.69$. Found: $\mathrm{C}, 46.72 ; \mathrm{H}, 3.99 ; \mathrm{N}$, 19.68 .

Copper(II) Chelate_- This chelate was prepared by shaking $30 \mathrm{ml}$ of aqueous $0.02 \mathrm{~m}$ cupric acetate in $\mathrm{pH} 3.5$ acetate buffer and $30 \mathrm{ml}$ of benzene solution of $250 \mathrm{mg}$ of methyl-azothiopyrine in a manner similar to that used to prepare the azothiopyrine copper(II) chelate. Recrystallization from benzene and petroleum benzin (1:5) gave dark-green fine needles. Yield, 60\%. mp 172-174 (dec.). Anal. Calcd for $\mathrm{C}_{22} \mathrm{H}_{22} \mathrm{Cu}-$ $\mathrm{N}_{8} \mathrm{~S}_{2}: \mathrm{C}, 50.22 ; \mathrm{H}, 4.21 ; \mathrm{N}, 21.30$. Found: $\mathrm{C}, 50.22 ; \mathrm{H}, 4.25 ; \mathrm{N}, 21.41$.

Extraction of Metal Chelates-One $\mathrm{ml}$ of $0.1 \%$ azothiopyrine or methyl-azothiopyrine in $\mathrm{MeOH}$ and $10 \mathrm{ml}$ of benzene were added to $40 \mathrm{ml}$ of an aqueous metal ion solution, and the mixture was shaken for about $10 \mathrm{~min}$ in a shaker. The metal ion was extracted as metal chelate in the benzene solution. When this solution was shaken with $20 \mathrm{ml}$ of aqueous $0.2 \mathrm{~N} \mathrm{NaOH}$ solution for about $5 \mathrm{~min}$, excess reagent was transferred to the alkaline solution without decomposition of the metal chelate. The absorbance of the remaining benzene solution was measured at the absorption maximum wavelength of the metal chelate.

Acknowledgement The authors wish to thank Mr. K. Sato and the other members of the Instrumental Analysis Center of Meiji College of Pharmacy for elemental analyses and NMR spectral measurements.

\section{References and Notes}

1) G. Schwarzenbach and H. Flaschka, "Die Komplexometrishe Titration," 2nd ed., Ferdinand Enke, 
Stuttgart, 1965; K. Ueno, "Chelatometric Titration," 16th ed., Nankodo, Tokyo, 1976; H. Wada, Bunseki Kagaku, 21, 543 (1972); S. Shibata, ibid., 21, 551 (1972); S. Imamura, ibid., 21, 556 (1972); R.G. Anderson and G. Nickless, Analyst, 92, 1093 (1967).

2) T. Tanaka, Yakugaku Zasshi, 92, 1252 (1972); idem, ibid., 92, 1435 (1972).

3) T. Tanaka, Yakugaku Zasshi, 91, 338 (1971); idem, ibid., 91, 393 (1971).

4) F.A. Snavely, W.C. Fernelius, and B.P. Block, J. Am. Chem. Soc., 79, 1028 (1957); F.A. Snavely, B.D. Krecker, and C.G. Clark, ibid., 81, 2337 (1959); F.A. Snavely and B.D. Krecker, ibid., 81, 4199 (1959). 